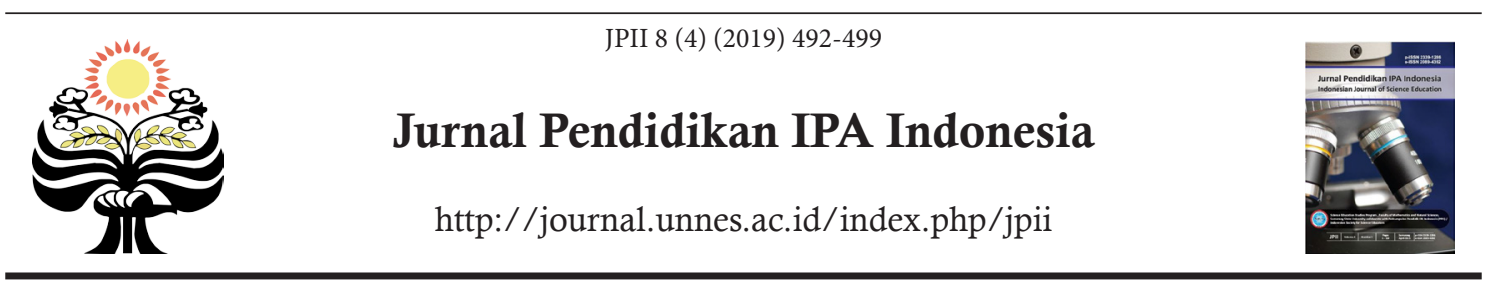

\title{
THE DEVELOPMENT OF PBL-BASED WORKSHEETS INTEGRATED WITH GREEN CHEMISTRY AND ETHNOSCIENCE TO IMPROVE STUDENTS' THINKING SKILLS
}

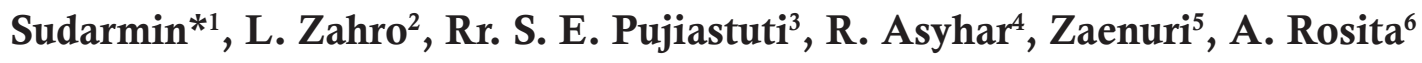 \\ ${ }^{1,5}$ Department of Chemistry, Faculty of Mathematics and Natural Science Universitas Negeri Semarang, \\ Indonesia \\ ${ }^{2}$ Teacher of MTs Negeri Semarang, Semarang, Jawa Tengah \\ ${ }^{3}$ Nursing Program, The Health of Polytechnic Semarang, \\ J1. Tritoagung Pedalangan Semarang, Indonesia \\ ${ }^{4}$ Chemistry Education Study Program, Faculty of Education and Teacher Training, Jambi University \\ ${ }^{6}$ Teacher of SMAN 1 Bae Kudus, Kudus, Jawa Tengah
}

DOI: 10.15294/jpii.v8i4.17546

Accepted: August $18^{\text {th }}, 2019$. Approved: December 27 $7^{\text {th }}, 2019$. Published: December $31^{\text {st }}, 2019$

\begin{abstract}
In today's global era, thinking skills are essential to be mastered by students. This research intended to develop and implement PBL-based worksheets integrated with green chemistry and ethnoscience to improve thinking skills, which included generic science skills and critical thinking skills. These skills were observed through learning outcomes, which were divided into three domains, i.e., cognitive, psychomotor, and affective. The cognitive aspect was assessed through pre- and post-test results, the psychomotor domain was valued through an essay test and observational sheets, and the affective domain was evaluated using questionnaires and observational sheets. This research was conducted with XI graders of MAN I Semarang and SMA Pekalongan. There were three rounds implemented; first, preliminary research which has observed the problems in chemistry learning, particularly on the hydrolysis topic and continued to the development of worksheets, then validated. The next round was the implementation of the worksheets. The $\mathrm{N}$-gain test was used to see the influence of the developed worksheets on the increase in critical thinking skills and generic science skills. The critical thinking scored 0.58 (moderate), while the generic science, which covered scale awareness and logical inference, scored 0.63 (moderate) and 0.73 (high), respectively. A paired t-test results revealed that there was a remarkable increase in the logical inference and awareness of scale. Moreover, the results of the study found that the applied worksheets were practical for cognitive, affective, psychomotor seen from the learning outcomes.
\end{abstract}

(C) 2019 Science Education Study Program FMIPA UNNES Semarang

Keywords: problem-based learning, ethnoscience, generic science skills, green chemistry, learning outcomes

\section{INTRODUCTION}

In the 21 st century, the development of science, technology, and information takes place very quickly and is full of competition. To anticipate and win this competition, Indonesi-

*Correspondence Address

E-mail: sudarmin@mail.unnes.ac.id ans must prepare themselves by growing and developing many competencies (Suardana et al., 2018). Thus, it brings the impact of a tight race in all areas of life. National education graduates must have competitive and comparative advantages according to national quality standards to win job opportunities in this global era. In line 
with the rapid development of IT and dynamic social change, it is necessary to prepare Indonesian science teachers who can compete freely and have the toughness in thinking, and act scientifically to solve problems encountered (Yokhobed et al., 2012). Educational institutions such as Universitas Negeri Semarang (UNNES) as the host of science and civilization developers have an essential role in improving the quality of human resources in the effort to educate the life of the nation and civilization (LPPM UNNES, 2015).

A preliminary study was conducted in two high schools, i.e., SMA 1 Pekalongan and MAN 1 Pekalongan, prior to the worksheets' development. The results of field observations, data reviews, and interviews of chemistry teachers at MAN 1 Semarang and High School (SMA) I Pekalongan. It was found that the students had difficulties in understanding chemistry subjects related to the hydrolysis process, acidity degree, and acid-base demanding high-level thinking skills. This low understanding was inversely proportional to the students' low thinking skills, problemsolving skills, generic science skills, and critical thinking skills.

Generic science skills are the ability to act and think based on the scientific knowledge owned by the scientific frame of mind (Ramlawati et al., 2014). Generic Science skills are learners' fundamental skills in comprehending scientific concepts and solve science problems; also, a provision to develop high-order thinking skills (Mulyani et al., 2016; Sumarni, 2018). The nine indicators of generic science skills include (1) direct and indirect observation; (2) sense of scale; (3) symbolic language; (4) logical self-consistency; (5) logical inference; (6) causality; (7) Mathematical modeling; (8) concept formation; and (9) spatial thinking skills/abstraction (Brotosiswoyo, 2000). On the other hand, Costa \& Kallick (2014) studied what critical thinking is, and the research unveiled that critical thinking is a mental process. At this point, people require to skillfully and actively conceptualize, apply, analyze, synthesize, and evaluate information to obtain an answer or conclusion

Learning activities will be more optimal if the used worksheets are associated with appropriate learning models and adjust to the demanded targets. Indonesia's 2013 curriculum requires Problem-Based Learning (PBL) to be implemented in the teaching and learning process. As argued by the Ministry of Education and Culture of Indonesia, Problem-Based Learning provides contextual problems stimulating students to learn. In the PBL situation, students in- tegrate knowledge and skills simultaneously and apply them in a relevant context. Febriani et al. (2017) developed problem-based worksheets and successfully improved students' creative thinking skills. Similarly, Ragilia et al. (2018) established problem-based worksheets by referring to behaviorism, cognitive, and constructivism theory. Further, it was proven that the students' critical thinking enhanced after using them.

Meanwhile, today's chemistry learning in Indonesia has not met the demands of the industrial revolution 4.0, which emphasize the 21 stcentury skills, especially problem-solving skills. These skills could be developed through problembased learning and STEM (Science, Technology, Engineering, and Mathematics) approach (Redhana, 2013). Moreover, chemistry learning in Indonesia has not been able to raise students' conservation awareness. Rosita et al. (2014) and Zahro et al. (2013) explained that students are less concerned about the environment, especially when conducting chemical practicum activities. In line with this, the students in both schools were observed to be careless when it comes to the measurements while weighing and making solutions, disposal of substances, and the arrangement of practicum tools. Similarly, Nuswowati et al. (2017) also found that chemistry learning students lacked environmental conservation traits. Departing from these findings, the researchers intended to establish worksheets based on problems that could raise students' environmental conservation awareness by adopting the green chemistry and ethnoscience approach.

The green chemistry is an approach that emphasizes environmentally-friendly activities during learning either in the use of chemical substances or the sequence of activities. This approach has been applied in UNNES's chemistry learning activities as an effort to cultivate conservation values, which become one of UNNES' vision. Referring to Hardati et al. (2016), there are ten conservation character values, including religious, honest, intelligent, impartial, responsible, care, tolerant, democratic, patriotic, tough, and polite. These values, as could be seen, are extracted from both social and spiritual values. Departing from this point, the two schools, SMA 1 Pekalongan and MAN 1 Semarang, were selected due to their distinct backgrounds. The first one is a public school, while the second one is Islamicbased school. Therefore, the researchers gathered different values living in these schools to be integrated into the developed worksheets.

In addition to Green Chemistry, Ethnoscience was chosen as an approach integrated 
into the development of the worksheets. Ethnoscience was selected as it investigates indigenous knowledge of the people and transforms it into a scientific one. The conservation knowledge lives in the community were dug up to be translated into conservation materials and included in the worksheets. The examples of indigenous knowledge included the terasering technique applied by Balinese people (Suardana et al., 2018) or preservation of Mangrove and National Park by Karimunjawa residents (Dewi et al., 2019). Moreover, the use of the ethnoscience approach has been proven to be able to develop thinking skills (Setiawan et al., 2017). With this in mind, this research objected to develop PBL-based worksheets integrated with green chemistry and ethnoscience and their influence on thinking skills. The developed worksheets discussed the hydrolysis topic, which is taught at the high school level.

The worksheets on the hydrolysis topic were employed to ameliorate the students' thinking skills. The assessed thinking skills were divided into two; critical thinking skills and generic science skills in which the later covered two out of ten indicators, namely logical inferences and awareness of scale. These skills were evaluated after the worksheets were implemented in the learning process. Moreover, these skills were mapped into three different domains of thinking; cognitive, affective, and psychomotor. The cognitive aspect revealed the enhancement of the students' grade after learning using the developed worksheets. The affective aspect, on the other hand, measured the students' conservation character values. At last, the psychomotor aspect calculated the students' generic science and critical thinking skills. The authors wish that this research could be referred to as one of the solutions to the problems related to the students' low thinking skills conservation characters as part of the principles of green chemistry and ethnoscience.

\section{METHODS}

This research was carried out in three rounds. First, a preliminary study that took place in two research sites; SMA 1 Pekalongan and MAN 1 Semarang. This prior study observed the learning obstacles faced by the students and the need for proper worksheets. Moreover, the learning outcomes of hydrolysis required improvements. The instruments of this study included the questionnaires of needs analysis, material and media expert's validation sheets, and pretestposttest questions and questionnaires of the conservation characters.
The second round was the development of the worksheets. At this stage, a Research and Development design was applied. The validation of the worksheets was done by three experts, namely education, green chemistry, and chemistry expert. An early design of the worksheets was tested in a small-scale trial to 12 students of XI IPA 4 MAN I Semarang to obtain readability data. The worksheets were revised based on the evaluation of the small group trial results. The next large group trial was conducted to 38 students of XI IPA 5 MAN I Semarang. Based on the trial, the worksheets did not need any revision and were ready to be applied to high school students.

The fixed worksheets were applied to 68 students of XI IPA 6 and IPA 7 in SMA I Pekalongan, who became the sample of this research, using pre- and post-test research design to determine the effect of student worksheets in improving the students' concept mastery (cognitive) using the t-test. Moreover, observational sheets were used to see the improvement of thinking skills (psychomotor) before and after using the developed worksheets. Then, the obtained data were analyzed using the $\mathrm{N}$-gain test, according to Hake (1999), to see the enhancement. Moreover, the students were asked to fill in the questionnaires to reveal the students' conservation characters (affective). The researchers also assessed the conservational characters during the lab work using the observational results. These instruments have been validated and declared valid.

\section{RESULTS AND DISCUSSION}

This section discusses the developmental results and the worksheets' impacts on the students' thinking skills based on three domains.

\section{Development Results of the PBL-based Worksheets Integrated with Green Chemistry and Ethnoscience}

The validation was done by three experts, namely education, green chemistry, and chemistry expert. The assessment results from the three experts were then quantized and calculated with Aiken's V formula. The quality of the student worksheets assessed included the feasibility of content, language, and graph. The average validation scores are presented in Table 1.

Table 1 shows that all aspects belonged to the 'very good' category, which means that the worksheets are valid. The data provided in Table 1 were the results obtained after the researchers revised some parts of the worksheets, as sugge- 
sted by the validators. The revisions included cover design, image display, font, and the contents of the student worksheets. This is consistent with Arsyad's (2005) statement that choosing the appropriate font size is significantly essential. The letter size is usually expressed in points per inch; the right font size for the text is 12 points. The size factor is relative for every person, but for the healthy eyes, it has been confirmed appropriate. This means that the font does not need to be enlarged or reduced. The image resolution should be augmented to avoid pixelation. Images, according to Suleiman (1998), are a crucial tool to give a concrete visual representation of the problem it describes. Images allow people to capture the idea or information contained within them brighter than words written or spoken expression.

Table 1. The Average Validation Results

\begin{tabular}{llll}
\hline No. & $\begin{array}{c}\text { Validation } \\
\text { Aspects }\end{array}$ & $\begin{array}{c}\text { Average } \\
\text { score }\end{array}$ & Category \\
\hline 1. & Feasibility of & 0.87 & very good \\
2. & Lontent & & \\
3. & Graph & 0.87 & very good \\
\hline
\end{tabular}

Moreover, the worksheets' legibility data were obtained from interviews with students in MAN I Semarang, and the observation of learning activities when doing the small-scale testing. The legibility results were used to improve the worksheets before being used in a large-scale trial and field trial. The interview results with the students about the worksheets' legality indicated that the developed worksheets have been feasible to use.

In terms of language, not all students thought that the language of the Student Worksheet is easy to understand. It is a reasonable condition because the speed of reading comprehension depends on the speed of the students' ability to grasp. It appears that the students' ability was relatively different in understanding the language in the worksheets. However, some terms should be given a more lucid explanation. Diction and compilation of sentence, are exceedingly essential for printed learning media as they pay a big credit to the communicativeness.

The established worksheets are equipped with observation and discussion sheets for the students. This is following Arsyad's (2005) statement, in providing printed learning media including student worksheets, it is necessary to consider the results of student response analysis, how students answer questions or do the exercises, and provide opportunities for additional exerci- ses. However, not all students thought the worksheets have accessible materials when using them in groups. This is a natural thing because there are times when some students find it difficult to interact and work with other students. This also might be caused by the number of members. According to Chiriac (2014), an ideal study group should not be too large, i.e., between four to eight people. Students are individual beings, different from each other. Differences in nature between students can sometimes lead to irritation and misunderstandings so that cooperation among group members is a little challenging to do. On the other hand, most students considered the observation and discussion sheets useful.

\section{The Influence of PBL-based Worksheets Integrated with Green Chemistry and Ethnoscience on Thinking Skills}

The thinking skills, as seen from the students' learning results after using the problembased worksheets integrated with green chemistry and ethnoscience, are divided into three domains; cognitive, psychomotor, and affective. The discussion of the results is presented as follows.

\section{Cognitive Domain}

The students' understanding of the concept of instructional materials was measured using integrated cognitive test questions on the hydrolysis topic. The fixed problem-based worksheets integrated with green chemistry and ethnoscience on hydrolysis topis were applied to 68 students of XI IPA 6 and IPA 7 at SMA I Pekalongan using preand post-test. The completeness of individual study can be seen from the post-test results. The learners are said to achieve mastery learning if the post-test result scores $\geq 75$ or more by using the left-sided t-test. The $\mathrm{H}_{0}$ is accepted if the $\mathrm{t}_{\text {count }}>\mathrm{t}_{\text {table }}$ -0.95 . the results obtained tcount $=4.252$ and ttable $=-1.996$, which means that tcount $>$ ttable. In other words, the students have reached the demanded mastery learning with $85.29 \%$ of classical completeness. This rate is favorable as it has passed the minimum classical mastery, $75 \%$. This proved that the problem-based worksheets are appropriately implemented to chemistry learning as they involved the students to actively participate in connecting the students' knowledge to produce a robust conceptual understanding. This is in accordance with the constructivism philosophy, which is adapted to the problem-based learning concepts. It enables learners to build their knowledge through the learning experience they have undertaken and reflected it on each step carried 
out in solving the provided problem (Ackay, 2009). Besides, there is a positive and significant relationship between chemistry and self-efficacy for everyday applications and critical thinking (Uzuntiryaki-Kondakci \& Capa-Aydin, 2013; Weaver et al., 2016).

\section{Psychomotor Domain}

This study investigated the influence of problem-based worksheets on thinking skills, which included generic science skills and critical thinking skills. The assessed skills of generic science covered two out of ten indicators, i.e., the logical inferences and awareness of scale.

The increase in skills was observed during the lab works before and after using the problem-based worksheets integrated with green chemistry and ethnoscience. Generic science and critical thinking skills were assessed using observational sheets by the researchers. The data were analyzed using the normality test, $\mathrm{N}$-gain, and ttest on SPSS 16 program. The results showed that the pretest and post-test data were typically distributed. The $\mathrm{N}$-gain calculation was performed on each generic science skill indicator and critical thinking skills, while the results are presented in Table 2.

Table 2. The Score of N-Gain for Thinking Skills

\begin{tabular}{cccc}
\hline No & Thinking Skills & $\begin{array}{c}\text { The Score of N- } \\
\text { Gain }\end{array}$ & $\begin{array}{c}\text { Achievement } \\
\text { Level }\end{array}$ \\
\hline Generic Science Skills & & moderate \\
1 & Awareness of scale & 0.63 & high \\
2 & Logical Inferences & 0.73 & moderate \\
\multicolumn{2}{l}{ Critical Thinking Skills } & 0.58 & mode \\
\hline
\end{tabular}

The obtained $\mathrm{N}$-gain scores were 0.63 , 0.78 , and 0.58 , respectively, for the awareness of scale, logical inferences, and critical thinking. The improvement of students' scale awareness was seen from their neatness in weighing and taking substances or solutions when doing chemical lab works. Moreover, the high logical inferences indicated their ability to conclude the hydrolysis practicum. The worksheets gave a task for the students to experiment on fertilizing peanut and spinach plants. They must provide a mixture of urea and compost with various compositions. For two weeks, the students were required to pay attention to their growth on which variants of fertilizer grow faster and why, as well as the conclusion.

Meanwhile, the significance test of generic science skills improvement showed that -tcount $<-$ ttable. The tcount for logical inference was $-50,176$ and $t$ count for awareness of scale was $-41,367$ while the ttable $(\alpha=0,05 ; \mathrm{df}=67)$ was $-1,966$. This means that the $t$-count was in the rejection area of $\mathrm{H0}$; in other words, there is a significant difference or improvement on generic science skills before and after learning using the problem-based worksheets integrated with green chemistry and ethnoscience. The improvement of generic science skills in this research is in line with Dibyantini et al.'s (2018) research results that learning with a problem-based learning model could improve generic skills of logic consistency, abstraction, symbolic language, modeling, logical inference, cause-effect, and scale understanding.
The logical inference in this study was developed when the students could draw a logical conclusion from given data or experimental data based on the salt hydrolysis theory/concept. On the other hand, the scale awareness was developed when the students calculating the salt mass or volume of water required in making a saline solution and measure the concentration of $[\mathrm{H}+]$ ions or hydrolyzed salt $\mathrm{pH}$ associated with the nature of the salt. Also, when the students made different dosages of fertilizer and organic fertilizer. The students having low awareness of scale considered the activities as a new knowledge that should be linked to relevant concepts. For example, to be able to calculate how much water volume is needed in making a saline solution with $\mathrm{pH} 4$, the students must know the unit volume $(\mathrm{dL}, \mathrm{L}$, $\left.\mathrm{cm}^{3}, \mathrm{dm}^{3}\right)$.

The enhancement of generic science skills, indeed, cannot be separated from the applied worksheets. The problem is used as a starting point to direct the students to find the concepts, understand the contextual materials, and perceive the materials associated with the application of the green chemistry principle. The students had to observe the effect of ammonium sulfate fertilizer with manure on plant growth and soil $\mathrm{pH}$ change directly, find alternative solutions to the problems provided, and invite the students to identify the salt properties using materials commonly found in everyday life. These learning activities made it easier for the students to understand and learn the 
topic as they simply associated new knowledge with their existing knowledge. This is in line with the results of Baharom \& Palaniandy's (2013) research which succeeded in improving the generic skills of direct observational science, logic inference, mathematical modeling, and conceptbuilding ability by applying problem-based learning because the problem-based learning model emphasizes critical thinking and analytical thinking to find out answers to the proposed problem. In other words, learners could study the materials systematically.

Critical thinking skills are parts of analytical skills or higher-order thinking skills. These skills include the skills of analyzing arguments, making inferences using inductive or deductive reasoning, judging or evaluating, and making decisions or solving problems (Lai, 2011). The critical thinking skills examined in this study focused on the use of conceptual and procedural knowledge to solve hydrolysis problems, acid-base solutions, and acidity $(\mathrm{pH})$ levels. The improvement of the problem-solving ability of students cannot be separated from the teaching aid uses, which in this study, was the problem-based worksheets integrated with green chemistry and ethnoscience - referring to Trianto (2010) learners, who try to solve their problems, experience more valuable knowledge. The results of this study are in line with research conducted by Redhana (2013), which stated that applying problem based learning in addition to improving problem-solving skills could also improve critical thinking skills since it has an impact on the thinking process. The students acquired inductive/deductive reasoning skills, analyzed, synthesized, rated information, and interpreted during the problem-solving process. In line with this, Valdez et al. (2015) also concluded in his research that learning by constructing previous knowledge experiences, exploratively, and interactively could develop students' critical thinking skills.

\section{Affective Domain}

The students' conservation characters were evaluated using questionnaires (filled by the students) and observational sheets during the lab works on the hydrolysis topic. The assessed values included religious, honest, intelligent, impartial, responsible, care, tolerant, democratic, patriotic, sturdy, and polite. A student is said to complete the mastery learning if the s/ he scores in either excellent or excellent category. The completeness at the first meeting reached $97.06 \%$, the second and third meetings reached
$98.53 \%$, and the last meeting reached $100 \%$. The materials used included products containing salt compounds, which could be encountered easily by the students in everyday life. They also used colored plants to be used as natural indicators. Practicum activities with green chemistry principles are in line with the research of Sudarmin (2013), which involved prospective chemistry teachers in using conventional materials in the lab activities. This made the students more enthusiastic and be more active in doing laboratory works.

The democratic was the most salient conservation character value compared to other characters, which could be observed through the students' teamwork while working in their respective groups. This happened due to problembased learning fused in the worksheets, which is very useful in conducting good cooperation among students. Similarly, Ackay (2009) revealed that problem-based learning could escalate cooperation in groups and communication skills, both written and oral. Further, environmental care gained the second-highest percentage after the democratic. Environmental care is the attitude and action to prevent the destruction of the surrounding natural environment. Problembased learning with green chemistry has a positive effect on environmental care. There are six principles that students learn about materials that avoid chemicals derivates, and they are (1) waste prevention; (2) designing safer chemicals; (3) safer solvent and auxiliaries; (4) designing degradable products; (5) use of renewable feedstocks; and (6) atom economy.

\section{CONCLUSION}

This study concluded that the established problem-based worksheets integrated with green chemistry and ethnoscience are useful to enhance students' thinking skills in three domains of thinking; cognitive, psychomotor, and affective. The incorporation of problem-based learning, green chemistry, and ethnoscience has been proven effective in assisting the students to be actively involved in the learning process, cultivate conservational characters, and increase the students' conceptual mastery on the hydrolysis topic. The researchers wish that high school chemistry teachers could employ the developed worksheets as a teaching-learning aid on the hydrolysis topic. Nonetheless, not all of the generic science skills indicators and conservation characters appeared on students. 


\section{REFERENCES}

Akcay, B. (2009). Problem-Based Learning in Science Education. Journal of Turkish Science Education, 6(1), 28-38.

Arsyad. (2005). Media Pembelajaran. Jakarta: PT Raja Grafindo Persada.

Baharom, S., \& Palaniandy, B. (2013). Problem-Based Learning: A Process for the Acquisition of Learning and Generic Skills. In Mohd-Yusof, K., Arsat, M., Borhan, M. T., de Graaff, Kolmos, A., \& Phang, F. A. (Eds.), PBL Across Cultures. Paper Presented at The 4th International Research Symposium on Problem-Based Learning 2013, Universiti Teknologi Malaysia, Putrajaya, Malaysia. Retrieved from https:// vbn.aau.dk/ws/files/80413126/samlet 1 . pdf\#page $=55$

Brotosiswoyo, B. S. (2000). The Fact of Physics Learning in Higher Education. Jakarta: The Project of Open University Development. Ministry of Education.

Chiriac, H. E. (2014). Group Work as an Incentive for Learning-Students' Experiences of Group Work. Frontiers in Psychology, 5, 558.

Costa, A. L., \& Kallick, B. (2013). Dispositions: Reframing Teaching and Learning. Corwin Press.

Dewi, C. A., Khery, Y., \& Erna, M. (2019). An Ethnoscience Study in Chemistry Learning to Develop Scientific Literacy. Jurnal Pendidikan IPA Indonesia, 8(2), 279-287.

Dibyantini, R. E., Silaban, R., \& Suyanti, R. D. (2018, December). The Implementation of Problem Based Learning Model in Improving the Generic Science Skill of Organic Chemistry on Teacher Candidates. In 3rd Annual International Seminar on Transformative Education and Educational Leadership (AISTEEL 2018). Atlantis Press.

Febriani, S., Sudomo, J., \& Setianingsih, W. (2017). Development of Student Worksheet Based on Problem Based Learning Approach to Increase 7th Grade Student's Creative Thinking Skills. Journal of Science Education Research, 1(1), $1-4$.

Hake, R. R. (1999). Analyzing change/gain scores. Unpublished [online]. Retrieved from http://www. physics.indiana.edu/ sdi/AnalyzingChangeGain.pdf.

Hardati, P., Setyowati, D. L., Wilonoyudho, S., Martuti, N. K. T., Utomo, A. P. Y. (2016). Buku Ajar Pendidikan Konservasi. Semarang: UNNES Press.

Lai, E. R. (2011). Critical Thinking: A Literature Review. Pearson's Research Reports, 6, 40-41.

LPPM UNNES. (2015). Rencana Strategis 2015-2019. Retrieved from http://1p2m.unnes.ac.id/file unduh/2015 renstra $1 \mathrm{p} 2 \mathrm{~m}$ unnes.pdf

Mulyani, S., Liliasari, L., Wiji, W., Hana, M. N., \& Nursa'adah, E. (2016). Improving Students' Generic Skill in Science through Chemistry Learning Using ICT-Based Media on Reaction
Rate and Osmotic Pressure Material. Jurnal Pendidikan IPA Indonesia, 5(1), 150-156.

Nuswowati, M., Susilaningsih, E., Ramlawati, R., \& Kadarwati, S. (2017). Implementation of Problem-Based Learning with Green Chemistry Vision to Improve Creative Thinking Skill and Students' Creative Actions. Jurnal Pendidikan IPA Indonesia, 6(2), 221-228.

Ragilia, N., Ambarita, A., \& Rusminto, N. E. (2018). Development of Problem Based Learning Model Learner Worksheet to Improve Critical Thinking Ability. IOSR Journal of Research \& Method in Education, 8(1), 65-72.

Ramlawati, R., Liliasari, L., Martoprawiro, M. A., \& Wulan, A. R. (2014). The Effect of Electronic Portfolio Assessment Model to Increase of Students' Generic Science Skills in Practical Inorganic Chemistry. Journal of Education and Learning, 8(3), 179-186.

Redhana, I. W. (2013). Model Pembelajaran Berbasis Masalah untuk Peningkatan Keterampilan Pemecahan Masalah dan Berpikir Kritis. Jurnal Pendidikan Dan Pengajaran, 46(1), 76-86.

Rosita, A., Sudarmin, \& Marwoto, P. (2014). Perangkat Pembelajaran Problem Based Learning Berorientasi Green Chemistry Materi Hidrolisis Garam untuk Mengembangkan Soft Skill Konservasi Siswa. Jurnal Pendidikan IPA Indonesia, 3(2), 134-139..

Setiawan, B., Innatesari, D. K., Sabtiawan, W. B., \& Sudarmin, S. (2017). The Development of Local Wisdom-Based Natural Science Module to Improve Science Literation of Students. Jurnal Pendidikan IPA Indonesia, 6(1), 49-54.

Suardana, I. N., Redhana, I. W., Sudiatmika, A. A., \& Selamat, I. N. (2018). Students' Critical Thinking Skills in Chemistry Learning Using Local Culture-Based 7E Learning Cycle Model. International Journal of Instruction, 11(2), 399-412.

Sudarmin, S. (2013). Kemampuan Generik Sains Kesadaran Tentang Skala sebagai Wahana Mengembangkan Praktikum Kimia Organik Berbasis Green Chemistry. Jurnal Pendidikan dan Pembelajaran (JPP), 20(1), 18-24.

Suleiman, A. H. (1998). Media Audio Visual untuk Pengajaran, Penerangan, dan Penyuluhan. Jakarta: Gramedia

Sumarni, W. (2018). The Influence of EthnoscienceBased Learning on Chemistry to the Chemistry's Literacy Rate of the Prospective Teachers. Unnes Science Education Journal, 7(2), 198-205.

Trianto. (2010). Model Pembelajaran Terpadu: Konsep, Strategi, dan Implementasinya dalam KTSP. Jakarta: Bumi Aksara.

Uzuntiryaki-Kondakci, E., \& Capa-Aydin, Y. (2013). Predicting Critical Thinking Skills of University Students through Metacognitive Self-Regulation Skills and Chemistry Self-Efficacy. Educational Sciences: Theory and Practice, 13(1), 666-670.

Valdez, A. V., Lomoljo, A., Dumrang, S. P., \& Dida- 
tar, M. M. (2015). Developing Critical Thinking through Activity-Based and Cooperative Learning Approach in Teaching High School Chemistry. International Journal of Social Science and Humanity, 5(1), 139-141.

Weaver, M. G., Samoshin, A. V., Lewis, R. B., \& Gainer, M. J. (2016). Developing Students' Critical Thinking, Problem Solving, and Analysis Skills in an Inquiry-Based Synthetic Organic Laboratory Course. Journal of Chemical Education, 93(5), 847-851.
Yokhobed, Sudarisma, S., \& Sunarno, W. (2012). Pembelajaran Biologi Menggunakan Model Pembelajaran Berbasis Masalah dengan Pendekatan keterampilan Proses Sains untuk Meningkatkan Motivasi Belajar dan Hasil Belajar. Jurnal Inkuiri, 1(3), 183-194.

Zahro, L. (2015). Pengembangan Lembar Kerja Berbasis Masalah Bermuatan Green Chemistry Untuk Meningkatkan Keterampilan Generik Sains Siswa (Doctoral Dissertation). UNNES, Pascasarjana, Semarang, Indonesia. 